JURNAL

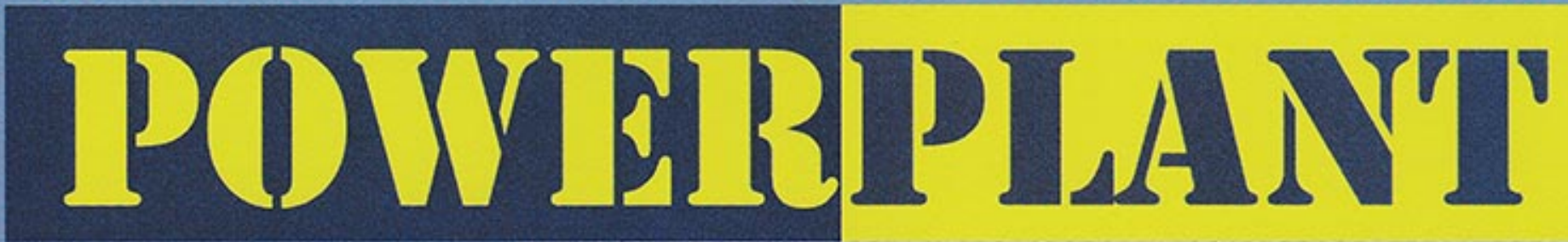

Roswati Nurhasanah

Jasmid Edy

Eza Brian Pradana

\section{Arief Suardi}

Vendy Antono

Al Asyi

Arisma Chairul Syarif Iman Kartolaksono R Jalu Eko Harjono

Nofirman

Yusuf Rasyid

Win Alfalah

Eko Sulistyo

Rahmat Ikhsan

Utami Wahyuningsih

Halim Rusjdi

Eko Sulistiyo

Sahlan

Jumiati

Intan Ratna Sari Yanti

Sri Yayi
Perancangan Boiler Dengan Memanfaatkan Sampah

Kering Untuk Bahan Bakar PLTU Mini 3 kW STT-PLN

Analisis Perbandingan Penggunaan Big Oil Gun dan Tiny Oil Gun terhadap Kosumsi Bahan Bakar Pada Saat Strat Up Unit di PLTU Banten Lontar

Uji Prestasi dan Emisi Diesel Berbahan Bakar Minyak Nabati Murni untuk Pembangkitan Daya di Daerah Terpencil

Pengukuran Suhu Pembakaran di Dalam Boiler : Pirometer Akuistik VS Pirometer Infared

Pengaruh Pemeliharaan Overhoul Turbo Charger

Terhadap Kinerja Mesin Unit VII PLTD Ampenan

Penanggulangan Korosi Pada Pipa Gas Dengan Metode Catodic Protection (Anoda Karbon) PT PGN Solution Area Cengkareng

Analisis Strategi Teknologi PLTS Fotovoltik di Indonesia Terhadap Nilai Eqivalensi dan Pemanfatan Per Wilayah

Pengembangan Model Pembelajaran Berbasis Tutorial Bagi Mahasiswa Teknik Mesin STT PLN

\begin{tabular}{|c|c|c|c|c|c|c|}
\hline 111 & & $\mathrm{SE}$ & OLAH & INGGI TEY & PLN (STT-PLN) & \\
\hline$\||\|||| \mid$ & JURNAL POWERPLANT & VOL. 5 & NO. 1 & HAL. 1.63 & NOVEMBER 2017 & ISSN No :2356-1513 \\
\hline
\end{tabular}




\title{
PENGEMBANGAN MODEL PEMBELAJARAN BERBASIS TUTORIAL BAGI MAHASISWA TEKNIK MESIN STT PLN
}

\author{
Jumiati \\ Progam Studi D3 Teknik Mesin STT \\ jumistt@gmail.com \\ Intan Ratna Sari Yanti \\ Progam Studi D3 Teknik Mesin STT \\ intan.yanti@gmail.com \\ Sri Yayi \\ Progam Studi D3 Teknik Mesin STT \\ Sriyayi24@yahoo.com
}

\begin{abstract}
Abstrak
Metode tutorial merupakan cara penyampaian bahan pelajaran yang telah dikembangkan dalam bentuk modul untuk dipelajari mahasiswa secara mandiri. Mahasiswa dapat mengkonsultasikan tentang masalah-masalah dan kemajuan yang ditemui secara periodik.Banyaknya keterbatasan yang dimiliki pengajar, dalam memilih metode yang tepat dalam mengajar pada jurusan teknik mesin menyebabkan dosen sulit merealisasikan tuntutan mahasiswa dalam percepatan belajarnya..Hal ini bisa kita lihat di perguruan-perguruan tinggi di sekitar kita, masih sangat banyak dosen yang menggunakan metode pembelajaran dengan cara konvensional,seperti ceramah, mencatat, merangkum dan sebagainya. Penelitian ini bertujuan untuk mengetahui keefektifan penggunaan metode tutorial dalam pengajaran di jurusan teknik mesin. Penelitian ini menggunakan metode penelitian dan pengembangan (Research and Development), dengan tahapan studi pendahuluan dilakukan dengan menerapkan pendekatan deskriptif kualitatif. Tahap pengembangan dilakukan dengan ujicoba terbatas pada model pengajaran konvensional dosen dengan menerapkan metode eksprimen (Single One Shot Case Study).Setelah ada perbaikan dari uji terbatas maka dilanjutkan dengan uji yang lebih luas dengan metode eksprimen dalam bentuk kelompok (one group pretestpostest). Terakhir adalah validasi model pengajaran tutorial dengan metode eksprimen. Hasil penelitian menunjukan bahwa metode mengajar tutorial pada jurusan teknik mesin lebih efektif daripada metode mengajar lama, baik pada aspek kecepatan pemahaman mahasiswa terhadap materi perkuliahan, kreativitas, dan hasil belajar mahasiswa.
\end{abstract}

Kata Kunci : metode tutorial, pengajaran, pengembangan, mahasiswa, eksprimen, teknik, mesin.

\begin{abstract}
Tutorial method is a way of delivering learning materials that have been developed in the form of modules for students to learn independently. Students can consult about the problems and progress encountered periodically. Many limitations teacher, in choosing the right method of teaching cause lecturer difficult to realize the demands of the students in this teach. Acceleration we can see at universities around us, still very much a lecturer who uses teaching methods in a conventional way, such as lectures, notes, summarizes and etc. Research aims to determine the effectiveness of the use of the tutorial method of teaching in the department of mechanical engineering. This study uses research and development (Research and Development), the stage of preliminary studies carried out by applying a qualitative descriptive approach. The development phase is done by trial limited to the conventional model of teaching faculty by applying experimental methods (Single One Shot Case Study) After no improvement on the limited test then continued with a broader test of the experimental method in the form of groups (one group pretest-posttest). The latter is a tutorial teaching model validation methods eksprimen. The result of research shows that tutorial teaching methods more effective than the old teaching methods, both on the speed aspect of students' understanding of the lecture material, creativity, and student results.
\end{abstract}

Keywords: method tutorial, teaching, development, student, experiments,mechanical, engineering 


\section{PENDAHULUAN}

\subsection{Latar Belakang}

Undang-Undang Guru dan Dosen Nomor 14 Tahun 2005 Pasal 8 disebutkan bahwa "Guru wajib memiliki kualifikasi akademik,kompetensi, sertifikasi pendidik,sehat jasmani dan rohani, serta memiliki kemampuan untuk mewujudkan tujuan pendidikan nasional”. Masing-masing kompetensi tersebut, yang wajib dimiliki seorang guru atau dosen adalah mengembangkan kurikulum yang terkait dengan bidang pengembangan yang diampu. Dari tuntutan-tuntutan sekaligus kewajibankewajiban ini guru ataupun dosen dituntut mampu menyusun bahan ajar secara kreatif dan inofatif. Membuat atau menyusun bahan ajar sebenarnya adalah perkara yang mudah. Namun, banyaknya keterbatasan yang dimiliki pengajar, seperti literatur metode pengajaran menyebabkan guru atau dosen sulit merealisasikan tuntutan tersebut.Hal ini bisa kita lihat di perguruan-perguruan tinggi di sekitar kita,masih sangat banyak dosen yang menggunakan metode pembelajaran dengan cara konvensional,seperti ceramah, mencatat, merangkum dan sebagainya. Padahal mereka tahu dan sadar bahwa metode pengajaran yang dilakukan sudah tidak sesuai lagi dengan kontek dan situasi sosial budaya peserta didik. Hal ini merupakan sebuah fenomena yang sungguh menyedihkan sekaligus sangat memprihatinkan bagi kita semua.

Berdasarkan kegelisahan itulah, penulis termotivasi untuk meneliti tentang metode tutorial.Sejatinya metode tutorial adalah metode pembelajaran dengan memberikan bimbingan belajar kepada mahasiswa secara individual.Karena itu metode ini sangat cocok diterapkan dalam model pembelajaran mandiri seperti pada pembelajaran jarak jauh dengan mahasiswa terlebih dahulu diberi modul untuk dipelajari.Alasan mahasiswa jurusan teknik sipil sebagai objek penelitian adalah pembelajaran di jurusan ini lebih banyak menghabiskan waktunya di lapangan dengan kegiatan praktek.

Selama ini,paradigma dan persepsi umum yang melekat di kalangan dosen adalah jumlah mahasiswa yang banyak dan keterbatasan waktu menyulitkan dosen dalam mentranfer pengetahuannya. Lalu bagaimana cara meluruskan persepsi itu ? Sebenarnya, caranya tidaklah sulit. Kuncinya yang pertama dan utama adalah mengendalikan faktor internal dalam diri kita. Kedua, dosen harus bisa merencanakan setiap kegiatan pembelajaran, dan mengubah segala persepsi tentang halangan dan hambatan menjadi peluang serta tantangan yang harus dihadapi dan dilakukan. Hal ini adalah cara yang efektif untuk mengubah diri menjadi pribadi yang berkualitas dan cerdas. Perbedaan implikasi antara penggunaan metode mengajar konvensional dan metode tutorial dalam proses pembelajaran sangat signifikan.

Mutu pembelajaran menjadi rendah ketika pendidik hanya terpaku pada cara-cara lama dalam pengajarannya, tanpa ada kreativitas untuk mengembangkan pola pengajaran secara inovatif. Namun, berbeda halnya jika kita memiliki keberanian untuk melepaskan diri dari belenggu kemalasan dan mendobrak kebiasaan buruk itu dengan berupaya secara kreatif menciptakan metode ajar sendiri yang lebih menarik,lebih variatif, dan sesuai dengan konteks sosial budaya peserta didik. Untuk itu pada kesempatan ini penulis mencoba meneliti dengan judul "Pengembangan Model Pembelajaran BerbasisTutorial Bagi Mahasiswa Teknik Mesin Sekolah Tinggi Teknik PLN”.

\subsection{Rumusan Masalah}

a) Bagaimana pelaksanaan metode pembelajaran saat ini oleh dosen jurusan Teknik Mesin Sekolah Tinggi Teknik PLN ?

b) Metode pembelajaran seperti apakah yang sesuai diterapkan pada jurusan teknik Mesin Sekolah Tinggi Teknik PLN ?

c) Bagaimana dampak penerapan metode tutorial yang dihasilkan terhadap aspek peningkatan prestasi mahasiswa?

\subsection{Model Tutorial}

Hasil kajian teori pembelajaran dengan metode tutorial dari pengamatan di lapangan seperti Ditunjukkan pada gambar 1.1 berikut ini. 


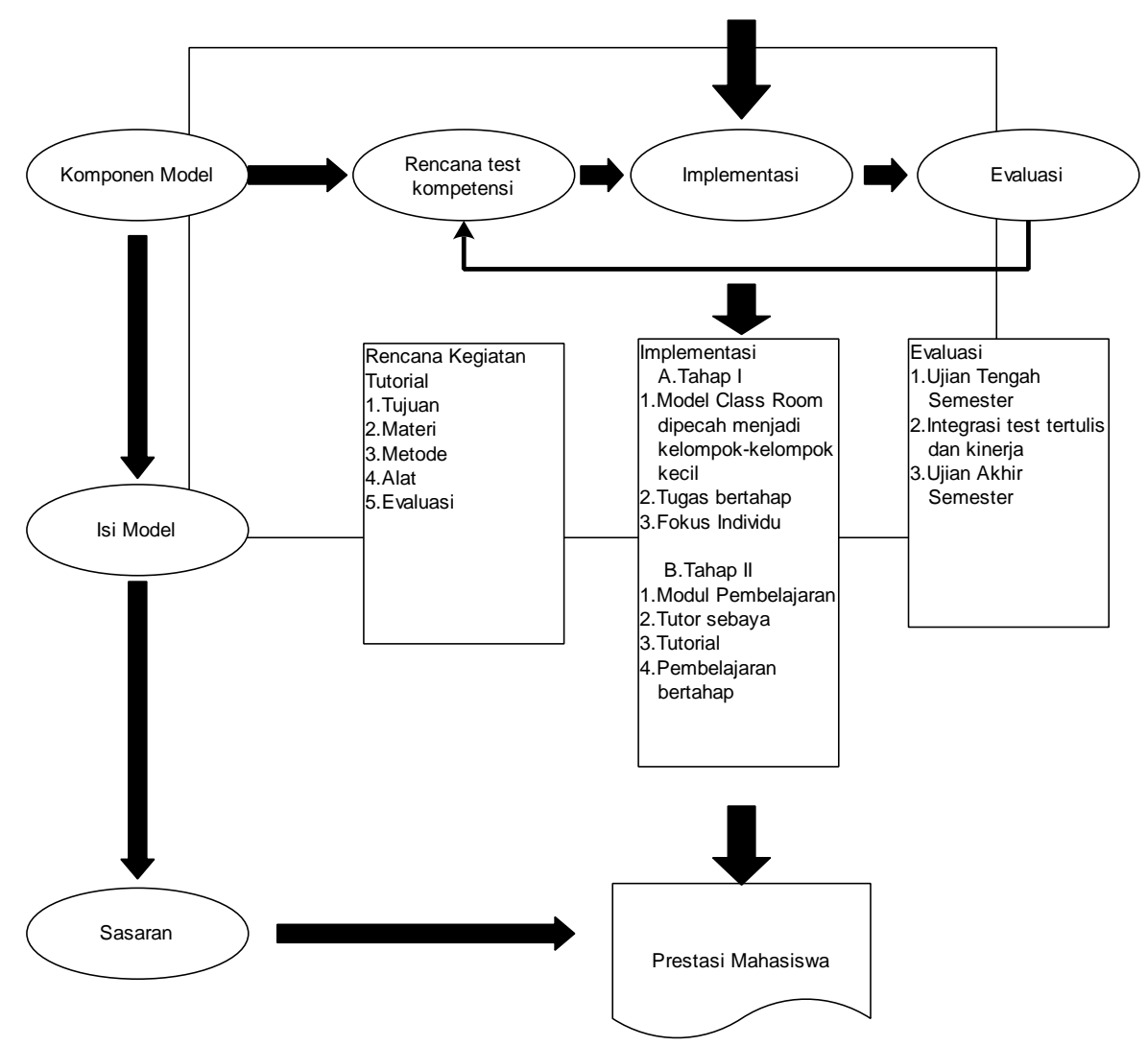

\subsection{Metode Penelitian}

Penelitian ini menggunakan metode penelitian dan pengembangan (Research and Development), dengan tahapan sebagai berikut.

a. Tahap studi pendahuluan dilakukan dengan menerapkan pendekatan deskriptif kualitatif.

b. Tahap pengembangan dilakukan dengan ujicoba terbatas pada model pengajaran konvensional dosen dengan menerapkan metode eksprimen (Single One Shot Case Study).Setelah ada perbaikan dari uji terbatas maka dilanjutkan dengan uji yang lebih luas dengan metode eksprimen dalam bentuk kelompok (one group pretestpostest)

c. Terakhir adalah validasi model pengajaran tutorial dengan metode eksprimen.

\subsection{Tujuan Penelitian}

a. Untuk mengetahui perkembangan metode belajar yang digunakan oleh para dosen jurusan Meknik Mesin.

b. Mencoba menggunakan metode tutorial untuk pembelajaran di jurusan Teknik Mesin. c. Untuk mengetahui keefektifan penggunaan metode tutorial dalam pengajaran di jurusan Teknik Mesin.

\section{TINJAUAN PUSTAKA}

Metode tutorial merupakan cara penyampaian bahan pelajaran yang telah dikembangkan dalam bentuk modul untuk dipelajari mahasiswa secara mandiri. mahasiswa dapat mengkonsultasikan tentang masalahmasalah dan kemajuan yang ditemui secara periodik.Pendekatan tutorial merupakan pendekatan belajar sendiriolehmahasiswa, menurut kecepatan masing-masing mahasiswa untuk melaksanakan proses perkembangan pendidikan secaramandiri.

Para tutor yang telah terlatih dalam menggunakan Pedoman Belajar Mengajar membawakannya dengan langkah-langkah sebagaimana diperintahkan di dalam Pedoman itu, pada jam-jam tertentu yang telah ditetapkan. Langkah-langkah itu ada beberapa macam, sesuai dengan sifat bahan pelajaran, sehingga tutor akan mengajar secara berlainan pada waktu membawakan bagian modul satu ke 
bagian modul yang lain. Namun pola umum yang dilakukan para tutor adalah meminta mahasiswa membuka buku pelajaran, menanyakan suatu pelajaran, memuji jawaban yang benar, meluruskan jawaban yang salah, menggilir latihan, mengetes, dan memaraf pedoman itu manakala telah selesai diajarkan.

Menurut Dedi Supriyadi sebagaimana yang dikutip Antonius, Tutor Sebaya adalah seorang atau beberapa orang peserta didik yang ditunjuk dan ditugaskan untuk membantu peserta didik yang mengalami kesulitanbelajar. Tutor tersebut diambil dari kelompok yang prestasinya lebih tinggi.

Menurut Ischak dan Warji, Tutor Sebaya adalah sekelompok peserta didik yang telah tuntas beban belajarnya, memberikan bantuan kepada peserta didik yang mengalami kesulitan dalam memahami bahan pelajaran yangdipelajarinya.

Satriyaningsih mengatakan yang dimaksud dengan Tutor Sebaya adalah siswa yang ditunjuk atau ditugaskan membantu temannya yang mengalami kesulitan belajar, karena hubungan antar teman pada umumnya lebih dekat dibandingkan dengan hubungan antar guru dan siswa.

Amin Suyitno mengatakan bahwa metode belajar yang paling baik adalah mengajarkan kepada orang lain. Oleh karena itu, pemilihan model pembelajaran Tutor Sebaya sebagai strategi pembelajaran akan sangat membantu siswa dalam mengerjakan materi kepadatemantemannya.

Suherman mengemukakan bahwa Tutor Sebaya adalah siswa yangpandai memberikan bantuan belajar kepada siswa yang kurang pandai. Bantuan tersebut dapat dilakukan temanteman di luar sekolah. Mengingat bahwa siswa merupakan elemen pokok dalam pengajaran, yang padaakhirnya dapat mengubah tingkah laku sesuai dengan yang diharapkan. Untuk itu, maka siswa harus dijadikan sumber pertimbangan di dalam pemilihan sumberpengajaran.

Bupati Karanganyar Hj. Rina Iriani dalam hasil tesis (S2) di UNS menjelaskan bahwa: "Metode Tutor Sebaya adalah bagaimana mengoptimalkan kemampuan siswa yang berprestasi dalam satu kelas untuk mengajarkan atau menularkan kepada teman sebaya mereka yang kurang berprestasi. Sehingga siswa yang kurang berprestasi bisa mengatasi ketertinggalan”. Adapun dasar pemikiran Tutor Sebaya adalah siswa yangpandai dapat memberikan bantuan kepada siswa yang kurangpandai.

Berdasarkan beberapa definisi tentang Tutor Sebaya di atas, maka dapat diambil simpulan bahwa istilah Tutor Sebaya ialah suatu strategi pembelajaran yang memanfaatkan mahasiswa yang mempunyai keistimewaan, kepandaian dan kecakapan di dalam kelas untuk membantu memberi penjelasan, bimbingan dan arahan kepada mahasiswa yang kepandaiannya agak kurang atau lambat dalam menerima pelajaran yang usianya hampir sama atau sekelas.

\section{HASIL DAN PEMBAHASAN}

\subsection{Hasil Penelitian}

\section{a. Penyelenggaraan Pembelajaran Saat ini}

Pembelajaran dengan metode konvensional yang terjadi selama ini tidak memberikan jalan kelua bagi mahasiswa yang menghendaki adanya percepatan belajar sesuai dengan kemampuan. Pemberian tugas-tugas pembelajaran mahasiswa belum mengoptimalkan modul dan instructional scheet, serta belum mengembangkan panduan spesifik sesuai metode pembelajaran yang diinginkan. Penyelenggaraan metode pembelajaran belum banyak didukung oleh institusi baik secara struktural maupun material.

\section{b. Pengujian Model}

Pengujian untuk mengembangkan model dilakukan melalui dua tahap, yaitu

\section{Pengujian terbatas}

Dalam eksprimen digunakan 10 mahasiswa yang diambil secara random. Selanjutnya 10 mahasiswa tersebut diminta untuk menilai kecepatan pemahaman terhadap pelajaran, kreativitas, dan hasil belajar sebelum diajar dengan metode tutorial dan sesudahnya.

\section{Pengujian yang lebih luas}

Pengujian lebih luas dapat dilakukan pada seluruh kelas kemudian dilanjutkan ke tingkat yang lebih luas yaitu seluruh jurusan di lingkup Sekolah Tinggi Teknik PLN. Berikut tabel data sebelum menggunakan metode tutorial. 
Tabel 3.1Sistem Pengajaran Metode Lama

\begin{tabular}{|c|c|c|c|c|}
\hline \multirow{2}{*}{$\begin{array}{c}\text { No. } \\
\text { Responden }\end{array}$} & \multicolumn{3}{|c|}{$\begin{array}{c}\text { Skor untuk } \\
\text { Butir No: }\end{array}$} & \multirow{2}{*}{ Jumlah } \\
\cline { 2 - 4 } & a & b & c & \\
\hline 1 & 1 & 2 & 1 & 4 \\
\hline 2 & 2 & 2 & 1 & 5 \\
\hline 3 & 1 & 2 & 1 & 4 \\
\hline 4 & 2 & 2 & 2 & 6 \\
\hline 5 & 1 & 1 & 1 & 3 \\
\hline 6 & 1 & 2 & 1 & 4 \\
\hline 7 & 2 & 1 & 1 & 4 \\
\hline 8 & 2 & 2 & 1 & 5 \\
\hline 9 & 1 & 2 & 1 & 4 \\
\hline 10 & 2 & 2 & 1 & 5 \\
\hline Jumlah & 15 & 18 & 11 & 44 \\
\hline
\end{tabular}

\section{Keterangan:}

$\mathrm{a}=$ kecepatan pemahaman terhadap pelajaran

$\mathrm{b}=$ kreativitas

c = hasil belajar

Instrumen penelitian untuk menguji metode mengajar baru dengan 3 indikator, diberikan kepada 10 mahasiswa yang telah diajar dengan menggunakan metode lama dan metode tutorial. Berdasarkan instrument tersebut diberikan nilai efektivitas metode mengajar lama dan metode tutorial berdasarkan kecepatan pemahaman terhadap materi perkuliahan, perubahan kreativitas, dan hasil belajar. Rentang skor setiap indikator adalah sebagai berikut.Kecepatan pemahaman: sangat cepat (4),cepat (3), agak cepat (2), lambat (1). Kreativitas sangat tinggi (4), tinggi(3), agak tinggi (2), renda (2). Hasil belajar sangat tinggi (4), tinggi (3), agak tinggi (2), rendah (1).

Tabel 3.2. Instrumen Untuk Mengukur Efektivitas Metode Tutorial

\begin{tabular}{|c|c|c|c|l|l|l|l|l|}
\hline \multicolumn{3}{|c|}{$\begin{array}{c}\text { Metode } \\
\text { Mengajar } \\
\text { Lama }\end{array}$} & \multicolumn{2}{|c|}{ Aspek-aspek Kinerja Sistem } & \multicolumn{4}{c|}{$\begin{array}{c}\text { Metode } \\
\text { Mengajar Baru }\end{array}$} \\
\hline 1 & 2 & 3 & 4 & $\begin{array}{l}\text { Kecepatan pemahaman terhadap } \\
\text { pelajaran }\end{array}$ & 1 & 2 & 3 & 4 \\
\hline 1 & 2 & 3 & 4 & Kreativitas & 1 & 2 & 3 & 4 \\
\hline 1 & 2 & 3 & 4 & Hasil Belajar & 1 & 2 & 3 & 4 \\
\hline
\end{tabular}

Untuk menghitung rata-rata efektivitas metode lama dan baru pertama-tama harus ditentukan skor kritorium/ideal untuk system kerja tersebut. Skor ideal: 4x3x10 =120 (4=skor tertinggi, $3=$ tiga butir instrument; $10=$ jumlah responden).
Selanjutnya skor ideal untuk setiap butir instrument $=4 \times 10=40 \quad$ (4 skor tertinggi; 10 jumlah responden. Berdasarkan tabel 3.1 diperoleh jumlah data $=44$. Dengan demikian efektivitas metode mengajar lama secara keseluruhan $=44: 120=0,36$ atau $36 \%$ dari kriteria yang diharapkan. Bila dilihat efektivitas metode mengajar berdasarkan kecepatan pemahaman terhadap materi perkuliahan $=15: 40=0,375$ atau 37,5 dari criteria yang diharapkan. Selanjutnya bila dilihat dari aspek kreativitas $=18: 40=0,45$ atau $45 \%$ dari criteria yang diharapkan. Bila dilihat dari aspek hasil belajar $=11: 40=0,275$ atau 27,5 dari criteria yang diharapkan. Jadi efektivitas metode mengajar lama terendah pada aspek hasil belajar mahasiswa, baru mencapai $27,5 \%$ dari yang diharapkan. Untuk menghitung efektivitas metode mengajar tutorial/baru cara menghitung seperti menghitung efektivitas metode mengajar yang lama. Skor ideal untuk seluruh system $=4 \times 3 \times 10=120$.Skor ideal setiap butir $=4 \times 10=40$.

Tabel 3.2. Sistem Kerja Metode Baru

\begin{tabular}{|c|l|c|}
\hline $\begin{array}{l}\text { Metode } \\
\text { Mengajar } \\
\text { lama }\end{array}$ & $\begin{array}{l}\text { Aspek-aspek kinerja } \\
\text { sistem }\end{array}$ & $\begin{array}{l}\text { Metode } \\
\text { Tutorial }\end{array}$ \\
\hline $37.5 \%$ & $\begin{array}{l}\text { Kecepatan pemahaman } \\
\text { mahasiswa terhadap } \\
\text { pelajaran }\end{array}$ & $92.5 \%$ \\
\hline $45.0 \%$ & Kreativitas Mahasiswa & $60.0 \%$ \\
\hline $27.5 \%$ & Hasil belajar & $90.0 \%$ \\
\hline $36.0 \%$ & Rata-rata & $80.8 \%$ \\
\hline
\end{tabular}

Berdasarkan ketentuan tersebut, maka efektivitas metode mengajar baru secara keseluruhan $=97: 120=0,808$ atau $80,8 \%$ dari criteria yang diharapkan. Dari perhitungan sudah terlihat adanya perbedaaan efektivitas antara metode mengajar lama dengan metode tutorial, yaitu efektivitas metode mengajar lama $=36 \%$ dari yang diharapkan, dan metode tutorial/baru $=80,8 \%$ dari yang diharapkan. Selanjutnya bila dilihat pada aspek kecepatan pemahaman mahasiswa terhadap materi perkuliahan $=37: 40=0,925$ atau 9,25\% dari yang diharapkan. Kreativitas murid $=24: 40=0,60$ atau $60 \%$ dari yang diharapkan. Hasil belajar $=36: 40=0,90$ atau $90 \%$ dari yang diharapkan. Untuk efektivitas metode tutorial yang terendah adalah pada aspek kreativitas mahasiswa, yaitu baru mencapai $60 \%$ dari yang diharapkan 
Tabel 3.3. Perbandingan Metode Lama Dan Metode Tutorial

\section{Kerja Metode Baru}

\begin{tabular}{|c|c|c|c|c|}
\hline \multirow{2}{*}{$\begin{array}{c}\text { No. } \\
\text { Responden }\end{array}$} & \multicolumn{3}{|c|}{$\begin{array}{c}\text { Skor untuk } \\
\text { butir no: }\end{array}$} & \multirow{2}{*}{ Jumlah } \\
\cline { 2 - 4 } & a & b & c & \\
\hline 1 & 3 & 3 & 4 & 10 \\
\hline 2 & 4 & 3 & 3 & 10 \\
\hline 3 & 3 & 3 & 3 & 9 \\
\hline 4 & 4 & 2 & 4 & 10 \\
\hline 5 & 3 & 2 & 4 & 9 \\
\hline 6 & 4 & 2 & 4 & 10 \\
\hline 7 & 4 & 2 & 4 & 10 \\
\hline 8 & 4 & 3 & 3 & 10 \\
\hline 9 & 4 & 2 & 3 & 9 \\
\hline 10 & 4 & 2 & 4 & 10 \\
\hline Jumlah & 37 & 24 & 36 & 97 \\
\hline
\end{tabular}

Beberdasarkan tabel 3.3 tersebut terlihat bahwa efektivitas metode tutorial jauh lebih tinggi dari metode lama. Rata-rata efektivitas metode lama $=36,0 \%$ dan metode tutorial 80,8\%.Kecepatan pemahaman mahasiswa terhadap pembelajaran dengan metode lama $=37,5 \%$ dan metode tutorial 92,5\%. Kreativitas mahasiswa yang diajar dengan metode lama $=45 \%$ dan metode tutorial $60 \%$. Hasil belajar mahasiswa yang diajar dengan metode lama 27,5\% dan metode tutorial $90 \%$. Berdasarkan data tersebut terlihat bahwa metode mengajar tutorial dapat meningkatkan kecepatan pemahaman murid terhadap materi kuliah dari $37,5 \%$ menjadi $92,5 \%$. Kreativitas mahasiswa dari $45 \%$ menjadi $60 \%$ dan hasil belajar mahasiswa dari 27,5\% menjadi $90 \%$. Simpulannya, metode tutorial lebih efektif dari metode lama.

Untuk membuktikan signifikasi perbedaan metode lama dengan metode tutorial,perlu diuji secara statistik dengan t-test berkolerasi. Rumus yang digunakan sebagai berikut.

Rumus

$$
t=\frac{\overline{X_{1}}-\overline{X_{2}}}{\sqrt{\frac{s_{1}^{2}}{n_{1}}+\frac{s_{2}^{2}}{n_{2}}-2 r\left(\frac{s_{1}}{\sqrt{n_{1}}}\right)\left(\frac{S_{2}}{\sqrt{n_{2}}}\right)}}
$$

Keterangan

$\bar{X}_{1} \quad$ : Rata-rata sampel (metode lama )

$\bar{X}_{2} \quad$ : Rata-rata sampel 2 (metode turorial)

S1 : Simpangan baku sampel 1 (metode lama)

S2 : Simpangan baku sampel 2 (metode tutorial)

$S_{1}{ }^{2}$ : Varians sampel 1

$S_{2}{ }^{2}$ : Varian sampel 2

$\mathrm{R}$ : Korelasi antara data dua kelompok

Untuk menggunakan rumus tersebut, maka perlu dicari terlebih dahulu korelasi nilai efektivitas metode mengajar lama dan metode tutorial,rata-rata, simpangan baku dan varians. Yang dikorelasikan adalah nilai total(nilai kolom paling kanan table 3.1 dan 3.2). Nilai efektivitas metode mengajar lama dan metode tutorial ditunjukkan pada table 3.4.Perhitungan menggunakan SPSS sehingga dapat ditemukan harga-harga untuk menghitung t. $\frac{-b \pm \sqrt{b^{2}-4 a c}}{2 a}$

Tabel 3.4

Nilai-Nilai Kinerja Sistem Yang Dikorelasikan

\begin{tabular}{|c|c|c|}
\hline No. & $X_{1}$ & $X_{2}$ \\
\hline 1. & 4 & 10 \\
\hline 2. & 5 & 10 \\
\hline 3. & 4 & 9 \\
\hline 4. & 6 & 10 \\
\hline 5. & 3 & 9 \\
\hline 6. & 4 & 10 \\
\hline 7. & 4 & 10 \\
\hline 8. & 5 & 10 \\
\hline 9. & 4 & 9 \\
\hline 10. & 5 & 10 \\
\hline$\sum \mathrm{X}$ & 44 & 97 \\
\hline $\bar{X}$ & 4.4 & 9.7 \\
\hline $\mathrm{s}$ & 0.84 & 0.48 \\
\hline$s^{2}$ & 0.711 & 0.23 \\
\hline $\mathrm{r}$ & 0.6 & 0.6 \\
\hline
\end{tabular}

Dalam penelitian ini dirumuskan hipotesis sebagai berikut.

Ho : Efektivitas metode kerja baru baru lebih kecil atau sama dengan sistem kerja lama

Ha : Efektivitas metode mengajar baru lebih baik dari dari metode kerja lama

Ho : $\mu_{1} \leq \mu_{2}$

На : $\mu_{1}>\mu_{2}$ 
Pengujian dengan menggunakan t-test berkorelasi uji pihak kanan karena hipotesis alternative (Ha) berbunyi “ lebih baik “.

$$
\begin{gathered}
t=\frac{4,4-9,9}{\sqrt{\frac{0.71}{10}+\frac{0.23}{10}-2.0,6\left(\frac{0.84}{\sqrt{10}}\right)\left(\frac{0.48}{\sqrt{10}}\right)}} \\
=-24.832
\end{gathered}
$$

Untuk menentukan perbedaan metode mengajar lama dan tutorial itu signifikan atau tidak, maka harga $\mathrm{t}$ hitung tersebut perlu dibandingkan dengan harga $\mathrm{t}$ table dengan $\mathrm{dk} \mathrm{n}$ $2=8$.Nilai-nilai dalam distribusi t, bila dk8,untuk uji satu pihak dengan taraf kesalahan $5 \%$ maka harga table $\mathrm{t}=1,86$ ( menggunakan tabel nilai dalam distribusi t) Bila harga t hitung jatuh pada daerah penerimaan $\mathrm{Ha}$, maka $\mathrm{Ha}$ yang menyatakan bahwa system kerja tutorial lebih baik dari system kerja lama diterima.Berdasarkan perhitungan ternyata $t$ hitung -24,832 jatuh pada penerimaan $\mathrm{Ha}$ atau penolakan Ho. Dengan demikian dapat disimpulkan bahwa terdapat perbedaan yang signifikan efektivitas metode mengajar lama dengan metode tutorial, di mana metode mengajar tutorial lebih efektif daripada metode mengajar lama, baik pada aspek kecepatan pemahaman mahasiswa terhadap materi perkuliahan, kreatifitas, dan hasil belajar mahasiswa.

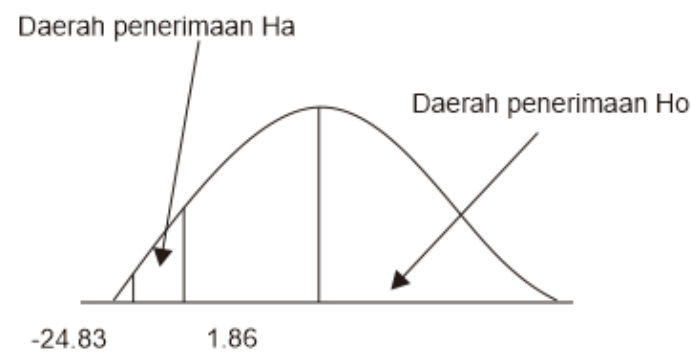

Dengan terujinya produk yang berupa metode mengajar tersebut, maka langkah pengujian produk untuk tahap terbatas ini bisa dikatakan selesai, langkah selanjutnya adalah revisi produk.

\section{REVISI PRODUK}

Pengujian afektivitas metode tutorial pada sampel yang terbatas tersebut menunjukkan bahwa metode mengajar ini ternyata yang lebih efektif dari metode lama. Perbedaan sangat signifikan, sehingga metode tutorial tersebut dapat diberlakukan pada kelas yang lebih luas dimana sampel tersebut diambil. Namun dari hasil pengujian terlihat bahwa kreativitas mahasiswa baru mendapatkan nilai $60 \%$ dari yang diharapkan . untuk itu maka desain metode mengajar perlu direvisi agar kreativitas mahasiswa dalam belajar dapat meningkat pada gradasi yang tinggi. Setelah direvisi, maka perlu diujicobakan lagi kelas yang lebih luas. Cara pengujian seperti contoh di atas. Setelah metode tutorial diterapkan selama setengah tahun atau satu tahun makan perlu dicek kembali, mungkin ada kelemahannya, kalau ada perlu segera diperbaiki lagi. Setelah diperbaiki maka dapat diproduksi masal, atau digunakan pada l;embaga pendidikan yang lebih luas.

Pengujian metode mengajar dengan mengumpulkan data melalui kuesioner ini dipandang kurang akurat, maka dalam kenyataan pengujian kecepatan pemahaman terhadap pelajaran diukur dengan waktu yang sesungguhnya (satuan menit) dan hasil belajar tidak diukur dengan menggunakan kuesioner, tetapi melalui test dengan instrument yang valid dan reliable.

Bila mengujikan produk dalam hal ini metode tutorial menggunakan desain pretest posttes control group design (ada kelompok eksperimen dan kontrol), maka untuk mencari efektivitas dan efesiensi system kerja baru, dilakukan dengan cara menguji signifikansi antara kelompok yang diajar dengan metode mengajar baru dengan kelompok yang tetap diajar dengan menggunakan metode lama. Bila produk yang berupa metode tutorial tersebut telah dinyatakan efektif dalam beberapa kali pengujian, maka metode mengajar baru tersebut dapat diterapkan pada setiap lembaga pendidikan. Pada produk teknologi telah dapat dibuat produk masal. Pembuatan produk masal ini dilakukan apabila produk yang telah diujicoba dinyatakan efektif dan layak untuk diproduksi masal.

\section{SIMPULAN}

a. Pembelajaran dengan menggunakan metode lama (ceramah,mencatat, tugas dan lain- lain ) yang terjadi selama ini tidak sejalan dengan prinsip pembelajaran berbasis kompetensi di jurusan Teknik Mesin Sekolah Tinggi Teknik PLN. 
b. Model pembelajaran dengan metode tutorial yang dikembangkan dapat meningkatkan prestasi belajar mahasiswa jurusan Meknik Mesin.

c. Desain metode tutorial memiliki tingkat keterterapan yang tinggi terutama bagi mahasiswa jurusan Teknik Mesin.

d. Metode mengajar tutorial lebih efektif daripada metode mengajar lama, baik pada aspek kecepatan pemahaman mahasiswa terhadap materi perkuliahan, kreativitas, dan hasil belajar mahasiswa jurusan Teknik Mesin Sekolah Tinggi Teknik PLN.

\section{DAFTAR PUSTAKA}

Alsyid, H. 1994. Dasar-dasar Statistika Terapan, disunting oleh Teguh Kismantoroadji. Bandung: Progam Pascasarjana, Universitas Padjaran.

Augustine,Yvonne dan Robert Kristaung. 2013. Metodologi Penelitian Bisnis dan Akuntansi. Jakarta : Dian Rakyat.

Amin, M. N. 2011. Kecurangan Laporan Keuangan: Menguak Perspektif Praktisi Keuangan. Jakarta: Lembaga Penerbit Unviersitas Trisakti.

Babbie, E. 1998. The process of Social Research, $8^{\text {th }}$ Edition. Belmont, CA: Wadsworth Publishing Company.

Bacharudin dan H.L. Tobing. 2003. Analisis Multivariate dengan SEM. Bandung
Cooper, D.R. dan P.S Schindler. 2006. Business Research Methods.Boston: Mc-Graw-Hill International Edition.

Christiawan dan Y. Jogi. 2005. "Aktivitas Pengendalian Mutu Jasa Audit Laporan Keuangan Historis [Studi Kasus Pada Beberapa Kantor Akuntan Publik di Surabaya]”, Jurnal Akutansi dan Keuangan Vol. 7, No. 1.

Hair, J.F. Jr., R.P. Bush and D.J. Ortinau. 2006. Maerketing Research: Within a Changing Inforation Tehnology, 3th Edition. Boston: MGraw Hill Irwin

Ischak dan Warji.1987. Program Remedial dalam Proses Belajar Mengajar.Jakarta

Nasution, S. 2003. Berbagai pendekatan Dalam Proses Belajar Mengajar.Jakarta : Bumi Aksara.

Sugiono.2006. Metode Penelitian Pendidikan. Bandung : Alfabeta.

Yamin, Martinis.2004.Strategi Pembelajaran Kompetensi.Jakarta : PT Gaung Persada Press. 